\title{
Marketing analysis of the residential real estate sector as a tool to plan the development of transport infrastructure
}

\author{
Yaroslav Lavrinenko ${ }^{1, *}$, Victoria Tinyakova $^{2}$, and Larisa Shishkina ${ }^{3}$ \\ ${ }^{1}$ Voronezh State Technical University, Moscow Avenue, 14, Voronezh, 394026, Russia \\ ${ }^{2}$ Russian state social University, Wilhelm Pieck street, 4, Moscow, 129226, Russia \\ ${ }^{3}$ Voronezh State Agricultural University, Ul. Mitchurina, 1, Voronezh, 394087, Russia
}

\begin{abstract}
Current methods for analyzing the residential real estate market have certain disadvantages. First of all, they are related to the heterogeneity of the market due to geographical differences. Secondly, it is various approaches to analyze the real estate sector. The real estate market is often analyzed only from the point of statistics and macroeconomic phenomena, without taking into account marketing components. However, effective analytics of the real estate sector should include marketing analysis. This analysis helps to understand the preferences and trends of past and current customers, specifically favored price. A forecast of future trends in real estate is created on the basis of this analysis. The authors suggested methodological approaches to analyzing the residential real estate sector with the use of marketing analysis.
\end{abstract}

\section{Introduction}

A stable development of the real estate market at all levels plays a major role in sustainable growth of the economy. The residential real estate market for any economy is a growth engine. However, the market, so as the whole economy, is subject to cycles. In order to improve its efficiency, it is proposed to consider analytics in the context of marketing. It is important for construction companies and real estate agencies to understand the demand, its state and trends.

Government statistics analyzes basic parameters such as the commissioning of residential buildings into operation in Russia, the number of apartments built, the average area and so on. But they are less to analyze what is in demand in the real estate market.

The top priority in analyzing the residential real estate sector is to understand the current level of demand, specifically the preferred budget of purchases depending on the area, type of real estate and price. The price of an apartment depends largely on the location rather than its quality and repair. Therefore, there is a buyer in each area with a certain budget for each type of property. By setting prices for objects below the demand, the seller loses part of the income. By setting prices higher than the market ones, higher than what the buyer is interested in - the seller gets an increased exposure time of his object on the market.

*Corresponding author: yaroslav_lav1@bk.ru 
As a result, real estate analyst should speak not only about the current situation in the context of what is offered in the market. One should take into account the marketing component, namely the current level of demand in a variety of interdependent indicators [1]. Assessment of the demand of objects by price, depending on the area and the period of exposure, is a basic indicator. It allows to assess current trends on the part of buyers and offer the best options to meet their preferences. In addition, marketing has significant features depending on the type of property, for instance, marketing the objects of high-rise construction should consider a number of characteristics of such buildings [2].

Market analysis enhances the efficiency to sell residential real estate, therefore, making construction sector and the economy more effective as a whole due to the fact that apartments find a buyer.

\section{Materials and Methods}

Proceeding to further consideration of the sector analytics experience with regard to marketing analysis, it should be noted that there are many parameters by which a particular market is evaluated. There have been lots of professional publications from various consulting agencies on this subject. Knight Frank, Blackwood and CRE are trying to provide marketing analysis in their reports. The main drawback of such publications is that they are focused on the commercial real estate market. The second disadvantage of such analytics and further reports is that the sampling base is too small. It is impossible to analyze the entire market if there is not enough information available. If these reports analyze demand, then only income and purchasing power of certain categories of citizens are considered. Of course, purchasing power is a key factor [3]. But it is important for participants of the real estate market to know the demand: what interests the buyer when the purchasing power decreases [4]. To do this, supply and demand analysis was conducted. In the "Materials and Methods" section the supply and demand in the residential real estate market will be analyzed.

\subsection{Analysis of the supply at the real estate market of Moscow}

In August 2018, the July tendencies in the Moscow real estate market mainly remained: prices for low-cost housing were rising against the background of the most affordable offers removal, while on the contrary expensive and heavily overvalued apartments became cheaper. It is noteworthy that the cost of high-budget real estate declined, despite the collapse of the ruble.

Related to the dollar growth, the dollar index of the cost of housing in Moscow in August fell by $2.1 \%$, approximately to $\$ 2,600$ per square meter. The ruble index increased by the same $0.3 \%$ as in June, and approached the mark of 167,800 rubles for the $\mathrm{m} 2$.

As in the previous month, the average level of ruble prices in August grew almost completely due to the "popular" segments: the low-cost housing index (the cost of $20 \%$ of apartments with the lowest price) increased by $0.5 \%$ in August [5], while the same index of the most expensive housing over the same period lost $0.6 \%$.

Moreover, the cheapest and the most low-quality supply on the market rose in price most of all: panel five-storey buildings rose in price by $1.5 \%$. Apartments in 9 -storey and 14 -storey buildings of Soviet construction rose by $0.7 \%$, brick five-story buildings - by $0.5 \%$. However, price growth in the segment of modern panel houses was zero in August. This situation suggests that the secondary market level of activity remains: the activity of buyers stimulates the upcoming growth in mortgage rates. Nevertheless, the effective demand is extremely limited: people can only afford the cheapest housing even if considering low mortgage rates [6]. 
Expensive housing, which has shown anomalous price stability for a long time, continues to fall in price. Prices for apartments in modern solid-cast and brick houses, declining by $1.7 \%$ in July, fell by another $1.4 \%$ in August. This happens despite the fact that in August the dollar rate has sharply increased, which many owners of high-budget real estate are still guided by. The cost of expensive housing is always reducing with some delay, but after a while this segment makes up for the delay.

The price development in terms of room quantity and geography show similar trends. The market leaders are single-bedroom flats and districts with democratic prices, while the outsiders of the market are multiroom apartments and prestigious districts.

Table 1. Apartment prices according to building types.

\begin{tabular}{|l|r|r|}
\hline Types of buildings & Aug 2018 & Jul 2018 \\
\hline $\begin{array}{l}\text { Old panel (5-storeyed buildings and other flats with a small } \\
\text { kitchen) }\end{array}$ & 139,360 & $1.50 \%$ \\
\hline Standard panel (9-14 stores, standard areas) & 142,768 & $0.70 \%$ \\
\hline Modern panel (from 16 stores and other flats with expanded areas) & 155,823 & $0.00 \%$ \\
\hline $\begin{array}{l}\text { Old brick (5-storeyed buildings and other flats with a small } \\
\text { kitchen) }\end{array}$ & 157,560 & $0.50 \%$ \\
\hline $\begin{array}{l}\text { Stalin-era building and standard brick (6-11 stores and other flats of } \\
\text { small areas) }\end{array}$ & 181,290 & $0.30 \%$ \\
\hline $\begin{array}{l}\text { Modern monolith and brick (monolith and brick buildings with } \\
\text { expanded areas) }\end{array}$ & 198,461 & $-1.40 \%$ \\
\hline All panel and block buildings & 145,984 & $0.70 \%$ \\
\hline All monolith and brick buildings & 179,104 & $-0.30 \%$ \\
\hline \multicolumn{2}{|c|}{ Apartment prices according to number of rooms } & \\
\hline & Aug 2018 & Jul 2018 \\
\hline One-bedroom flat & 162,318 & $2.30 \%$ \\
\hline Two-bedroom flat & 163,154 & $0.00 \%$ \\
\hline Three-bedroom flat & 160,518 & $-0.60 \%$ \\
\hline Multi-bedroom flat & 186,177 & $-1.70 \%$ \\
\hline
\end{tabular}

Housing prices by districts are also different and significantly vary depending on the class of housing.

Table 2. Apartment prices by districts.

\begin{tabular}{|l|r|r|}
\hline & Aug 2018 & Jul 2018 \\
\hline Central District & 289,717 & $0.00 \%$ \\
\hline North District & 164,376 & $0.80 \%$ \\
\hline Northeast District & 146,562 & $1.40 \%$ \\
\hline Eastern District & 152,736 & $-0.70 \%$ \\
\hline Southeast District & 135,694 & $0.80 \%$ \\
\hline Southern District & 143,154 & $0.70 \%$ \\
\hline Southwest District & 199,554 & $0.30 \%$ \\
\hline West District & 183,541 & $-0.80 \%$ \\
\hline Northwest District & 170,936 & $-0.50 \%$ \\
\hline
\end{tabular}




\begin{tabular}{|c|c|c|}
\hline All areas outside Moscow Ring Road & 124,054 & $1.20 \%$ \\
\hline \multicolumn{3}{|l|}{ "Expensive" and "cheap" housing } \\
\hline & Aug 2018 & Jul 2018 \\
\hline $\begin{array}{l}\text { Index of cost of "expensive" housing ( } 20 \% \text { of the most expensive } \\
\text { apartments) }\end{array}$ & 273,768 & $-0.60 \%$ \\
\hline Index of cost of "cheap" housing ( $20 \%$ of the cheapest apartments) & 115,758 & $0.50 \%$ \\
\hline Bundle index (the ratio of the cost of "expensive" to "cheap") & 2.37 & $-1.20 \%$ \\
\hline
\end{tabular}

In previous years, a rise in prices of cheap housing and a decline in process of expensive one could indicate the stabilization of the housing market, if not its reversal. However, the deterioration of the macroeconomic situation fraught with an increase in mortgage rates and the huge supply of new buildings now do not offer hope for such a scenario. Therefore, the price increase in recent months is not the bottom of the market, but a local step, after which the decline in the cost of housing will resume. However, the new building market will most likely be the first to increase the gap between supply and demand.

\subsection{Analysis of the supply at the real estate market of Voronezh}

The authors propose to consider the housing market in Voronezh as an example of a regional market. The demand is analyzed and considered in more detail in the Results section.

In August 2018, real estate prices in Voronezh increased: $+0.2 \%(+103$ rubles per $\mathrm{m} 2)$. Now housing in Voronezh costs an average of 43,913 rubles per square meter. From the beginning of the year, the apartments went up by 665 rubles per square meter $(+1.5 \%)$.

If looking at last year August, then in 2017 the value of real estate grew: $+0.3 \%$. Then a square meter cost 42982 rubles, which is 931 rubles less than now.

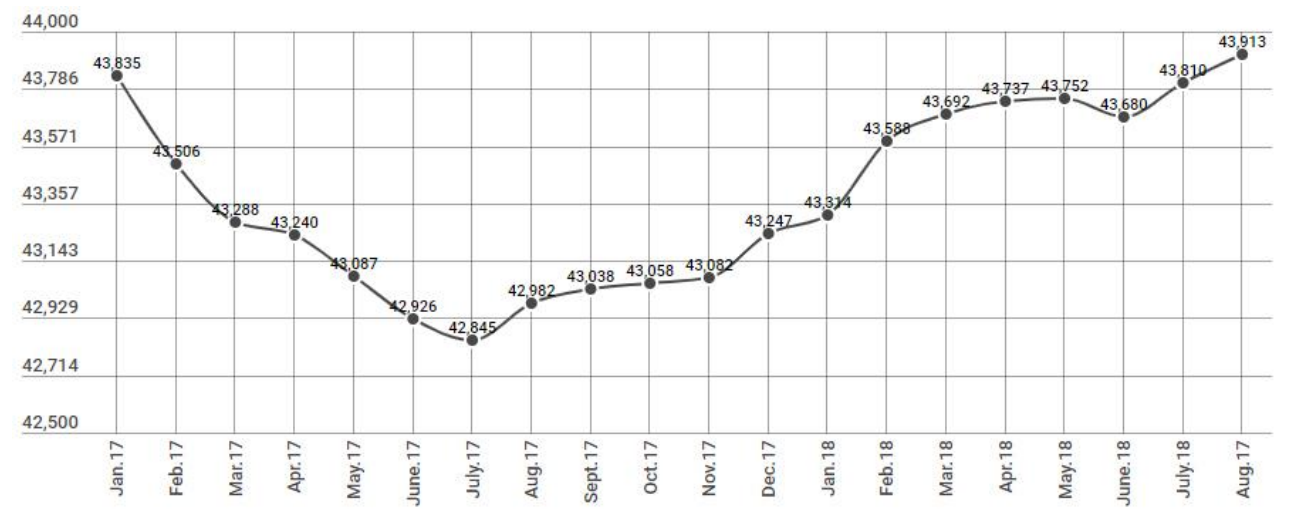

Fig. 1. The dynamics of prices for apartments in Voronezh from the beginning of 2017.

The average price per square meter in new buildings in Voronezh for August decreased: $-0.1 \%$ to 43577 rub./sq.m. (-48 rubles per square meter.). Last year in August, the average price of new buildings amounted to 42,692 rubles per square meter. ( +885 rubles per year) [7].

Curious situation has developed on the secondary market: the price for secondary housings has grown unlike for new buildings: $+0.4 \%(+195$ rubles per square meter $)$ and stopped at the level of 44,100 rubles per square meter. In August 2017, the average price in the secondary market was 43170 rub./sq.m. (+930 rubles per year) [7]. 
Table 3. Price of housing at the end of August in Voronezh.

\begin{tabular}{|c|c|c|c|c|}
\hline Segment & $\begin{array}{l}\text { Growth in } \\
\text { August, \% }\end{array}$ & $\begin{array}{l}\text { Price, } \\
\mathrm{rub} / \mathrm{m}^{2}\end{array}$ & $\begin{array}{l}\text { Growth in August, } \\
\mathrm{rub} / \mathrm{m}^{2}\end{array}$ & $\begin{array}{l}\text { Growth for } \\
\text { the year }\end{array}$ \\
\hline \multicolumn{5}{|c|}{ General index by room number } \\
\hline 1 bedroom flat & $0.10 \%$ & 44,807 & 45 & $0.90 \%$ \\
\hline 2 bedroom flat & $0.20 \%$ & 43,935 & 93 & $1.50 \%$ \\
\hline 3 bedroom flat & $0.40 \%$ & 43,522 & 171 & $2.10 \%$ \\
\hline \multicolumn{5}{|c|}{ Indexes of secondary housing by room number } \\
\hline 1 bedroom flat & $0.30 \%$ & 45,658 & 126 & $1.50 \%$ \\
\hline 2 bedroom flat & $0.50 \%$ & 44,343 & 202 & $1.80 \%$ \\
\hline 3 bedroom flat & $0.80 \%$ & 43,432 & 332 & $2.40 \%$ \\
\hline \multicolumn{5}{|c|}{ Indexes of new housing by room number } \\
\hline 1 bedroom flat & $0.04 \%$ & 43,578 & 18 & $-0.20 \%$ \\
\hline 2 bedroom flat & $-0.10 \%$ & 43,142 & -62 & $0.70 \%$ \\
\hline 3 bedroom flat & $-0.30 \%$ & 43,683 & -152 & $1.60 \%$ \\
\hline \multicolumn{5}{|c|}{ Building material indexes } \\
\hline Brick & $0.20 \%$ & 43,928 & 94 & $0.60 \%$ \\
\hline Panel & $0.40 \%$ & 40,030 & 188 & $1.30 \%$ \\
\hline \multicolumn{5}{|l|}{ Type indexes } \\
\hline Khrushchev-era house & $0.60 \%$ & 40,407 & 372 & $0.90 \%$ \\
\hline Brezhnev-era house & $0.80 \%$ & 40264 & 648 & $1.60 \%$ \\
\hline $\begin{array}{l}\text { Post-Khrushchev-era house } \\
\text { "Cheshka" }\end{array}$ & $0.30 \%$ & 41746 & 319 & $0.80 \%$ \\
\hline New & $0.00 \%$ & 44572 & 351 & $0.80 \%$ \\
\hline
\end{tabular}

According to the Bank of Russia in July 2018 a record volume of mortgage was issued in the Voronezh region since the beginning of the year: 3.135 billion rubles, with a quantity of 1,938. Dynamics for the years 2015-2018. next:

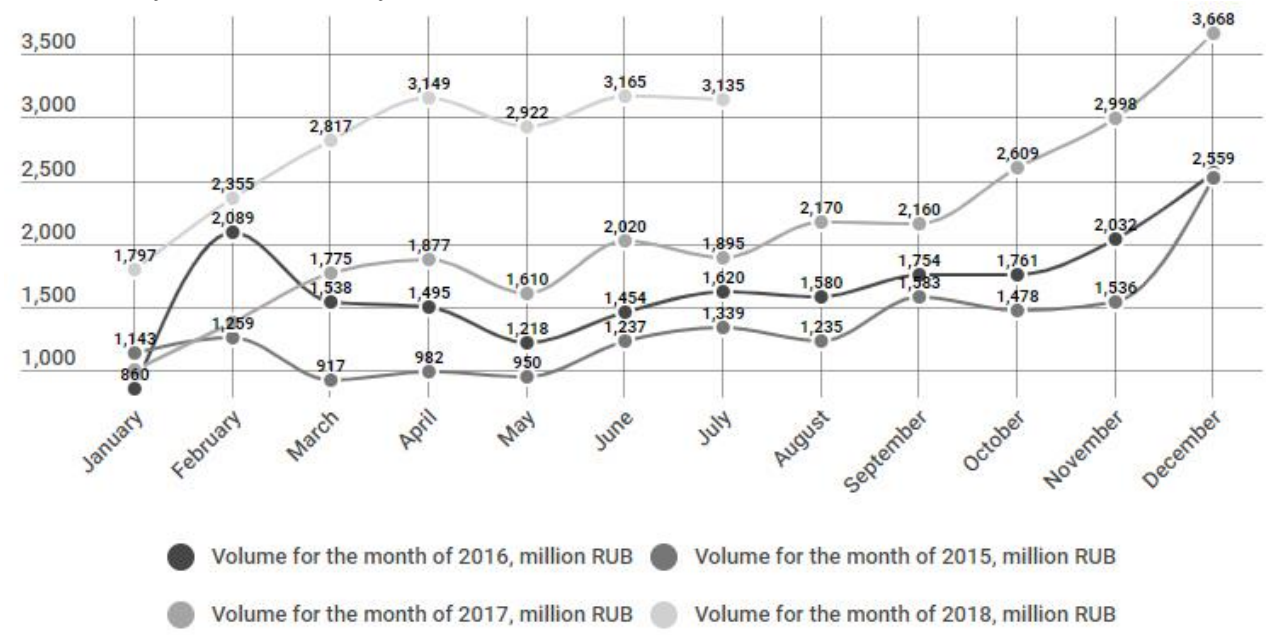

Fig. 2. Dynamics of mortgage loans in Voronezh and the region by year. 
The average size of the loan increased again to 1.6176 million rubles, the interest rate on housing loans decreased to $9.41 \%$. The average term of mortgage loan in the Voronezh region is 199.7 months (16.64 years).

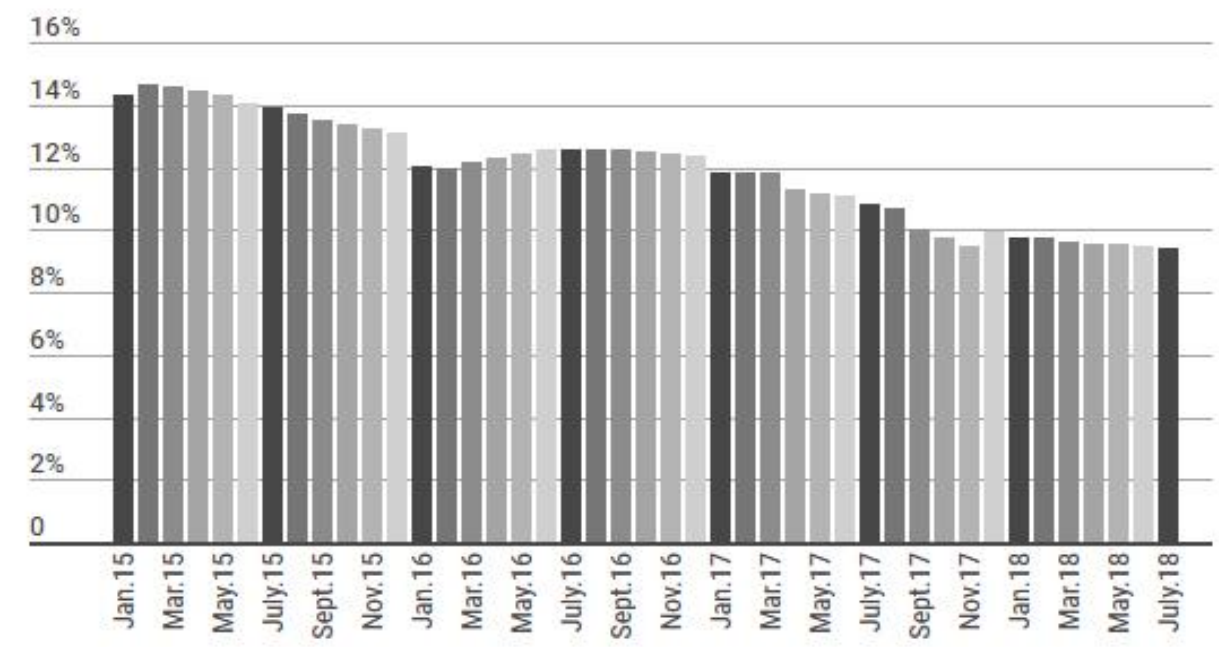

Fig. 3. Mortgage interest rate dynamics.

Then the marketing analysis of the demand in the residential real estate market of Voronezh is presented. The demand is analyzed on the basis of INFOLINE company data, particularly on the basis of attendance of certain real estate objects (announcements) for the first half of 2018. First, the budget of the buyer is estimated and options that he had a look at the most. $50 \%$ of all ad views got in the range from 1.3 to 2.4 million rubles.

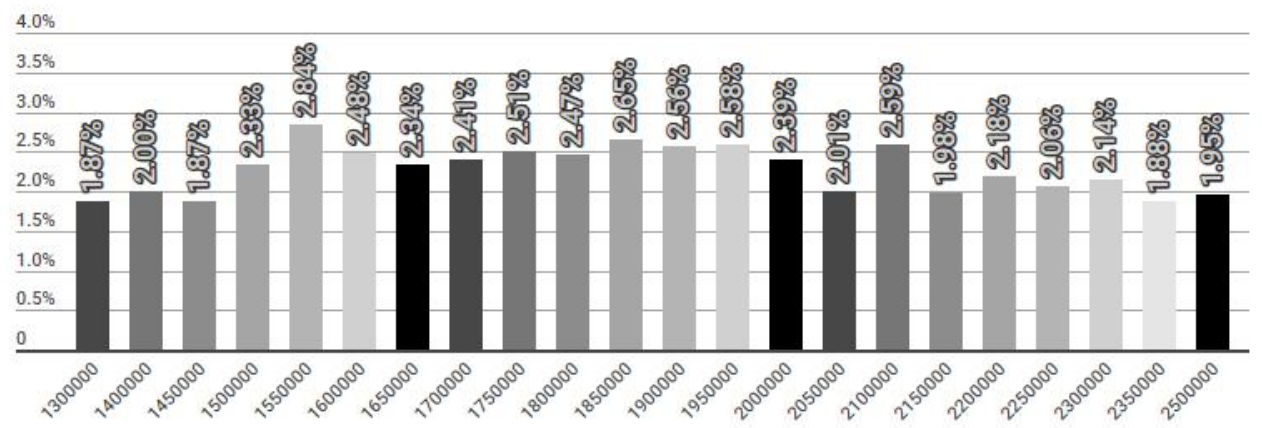

Fig. 4. The range of the most high-demanded housing prices for the $1^{\text {st }}$ half of 2018 .

If looking at the ranges in the context of areas and 1 or 2 bedroom apartments, the dynamic is presented below [8].

The duration of exposure is also an important factor. For the first half of 2018, the average sale time was 255 days. However, to assess the exposure, it is more relevant to use the period of exposure of the secondary housing - 238 days. If comparing with October $2008-49$ days [8]. 
Table 4. Price ranges of demanded housing by districts and number of rooms.

\begin{tabular}{|l|l|l|}
\hline District & Price range, mln rubles & \\
\hline & 1 bedroom flat & 2 bedroom flat \\
\hline Zheleznodorozhnyy & $1.20-1.55$ & $1.60-2.20$ \\
\hline Kominternovskiy & $1.45-1.90$ & $2.10-3.10$ \\
\hline Levoberezhnyy & $1.00-1.45$ & $1.50-2.20$ \\
\hline Leninskiy & $1.35-2.10$ & $1.55-2.10$ \\
\hline Sovetskiy & $1.15-1.50$ & $1.50-2.10$ \\
\hline Central & $1.40-2.00$ & $1.70-3.00$ \\
\hline
\end{tabular}

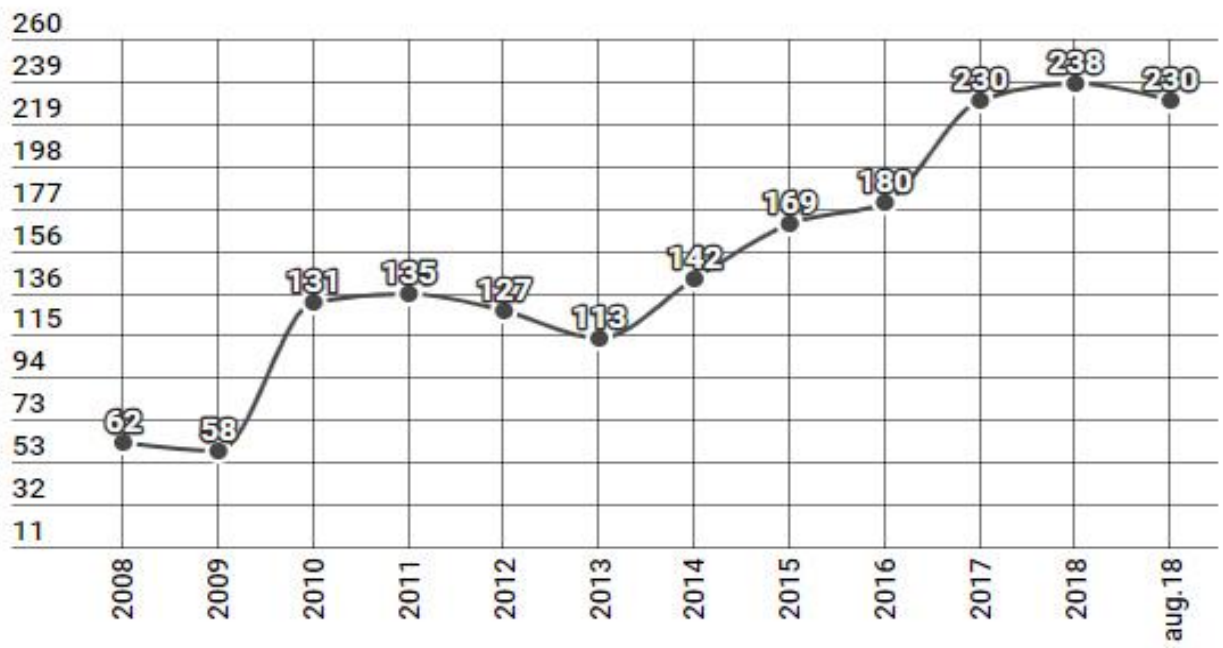

Exposition of the "resale apartment" at the beginning of each year, days

Fig. 5. Dynamics of exposure on the housing market in Voronezh since 2008.

\section{Results}

The income dynamics of the population, which dramatically decreased during the 2014 crisis, remains negative. At the end of 2017, real disposable incomes of Moscow citizens decreased by $1.4 \%$ compared to 2016 . In 2018 , after a slight increase in connection with the elections (due to increased payments to state employees and retirees), the indicator fell again in May by $12 \%$ compared to last year.

At the same time, as it was mentioned above, sales of new buildings have grown in the past two years, and at the end of the last year, there was a revival in the secondary market. The main driver of demand for housing was a very rapid decline in loan rates. In the first half of 2018 , the weighted average issue rate was $9.62 \%$ (-1.88 pct compared to the first half of 2017), including $9.26 \%$ on loans for new buildings (-1.45 pct as of June 2017), and for the purchase of secondary housing $-9.57 \%$ (-1.73 percentage points). Thanks to cheaper mortgages, the number of housing mortgage loans issued in Moscow and the Moscow 
region in the first half of 2018, according to the Bank of Russia, increased 1.6 times in annual terms to 72.2 thousand units. Even more - 1.7 times (up to 271.3 billion rubles) - the volume of mortgage issuance increased: since the incomes of the population stagnated at best, and savings were exhausted, buyers were forced to replace their own funds with credit [9].

Mortgage became cheaper after the reduction of key rate of the Bank of Russia, which dropped from 10 to $7.25 \%$ from March 2017 to last March. However, Central Bank did not reduce the rate at the last three meetings, explaining this by increased macroeconomic and inflationary risks, and promised to return to addressing this issue no earlier than 2019. However, monetary policy is unlikely to soften next year. On the contrary, Central Bank of the Russian Federation raised the key rate taking into account new USA sanctions.

"Act on the protection of American security from Kremlin aggression 2018" introduced for consideration by the US Senate in early August implies a ban on operations with new issues of the Russian government debt with a circulation period of more than two weeks, as well as a ban on dollar operations for Russian state banks.

The announcement of these measures has already led to the sale of Russian security papers and the collapse of the ruble. In just ten days, the rate of the domestic currency fell by more than $8 \%$, from 62.5 rubles for the dollar at the end of July to 67.7 rubles on August 10. At the same time, the yield on 10-year Russian government bonds (federal loan bonds) reached $8.32 \%$ per annum for the first time since January 2017, and the RTS index sank to a minimum since August 24, 2017.

If sanctions are imposed, the attraction of foreign funding for the Russian state, banks and companies, which is already very complicated by the sanctions in 2014, will significantly increase in price. This means that the interest rates within the country will go up to compensate for the sources of borrowed funds that are lost. The key rate, the yield of bonds and deposits will grow. Mortgage will inevitably become more expensive.

What is even worse, the real incomes of the population will suffer not only because of sanctions and the weakening of the ruble, but also due to the increase in VAT from 2019. Against the background of rising inflation, people will have to spend more and more on everyday needs, while their savings and the ability to postpone something for large purchases, such as real estate, will be greatly reduced, even if the deterioration of the macroeconomic situation does not lead to a sharp reduction in wages, as it was in 20142015.

Suspending a fall and a small price rebound in some segments in recent months is a temporary phenomenon, mainly due to sharply cheaper mortgages, and not evidence of a market reversal. In the foreseeable future, housing prices in the Moscow region will begin to decline again amid a widening gap between the demand level and supply volume.

There is a theoretical possibility that not all of the planned volumes will be brought to the market due to the massive bankruptcy of developers who could not withstand the competition, toughening of the legislation, etc. However, considering the level of marginality of the construction business in Moscow, which is still high, this development is hardly probable. Of course, the ruin of certain companies is not excluded, but there is always someone willing to take their place, because the Moscow market is still very attractive for developers from the regions. Therefore, if not all, then most of the planned projects will enlarge the supply volumes, which will have a significant pressure on the cost of housing.

In the secondary market, prices will remain at the current level for a relatively long time. Private sellers will as usual resist the decline in the cost of their apartments, although in the end the economy will still prevail over psychology. Meanwhile in the primary market, the increase in discounts for specific customers is expected, as well as greater spread of discount promotions, etc. New facilities will come out with a lower price tag than 
existing ones, and the increase in the cost of a meter as the readiness stage rises will be reduced to a minimum. As a result, the average market level of prices will decline by 5-7$10 \%$ per year, and the end of 2020-2021 it will drop approximately by $15-20 \%$.

\section{Discussions}

For the real estate market, the most important thing is to understand the demand in the context of the current supply. This is especially relevant against the backdrop of an unstable macroeconomic situation and the crisis in construction. The most accessible method of analysis is the analysis of the supply, particularly of price and volume. In our study, we divided apartments by type, number of rooms, district and wall material.

Marketing analysis of demand allowed identifying new wishes of buyers in the housing market in Voronezh. We saw that customer preferences depend not only on price, but also on the area. In each area and for each type of property there is a certain budget. Builders and real estate agencies need to take into account not only the current indicators of supply, but also the demand. Of course, only those companies that have a large incoming flow of bids can effectively assess demand. In our case, we estimated the demand for the real estate market in Voronezh on the basis of data from INFOLINE company.

Sustainable development of the real estate market depends on the adequacy of the analysis of its current state and forecasting in the future. Therefore, the most important task of analyzing the housing market in the regions is to develop a system for assessing the current state of supply and demand and forecasting future trends in order to increase the competitiveness of the industry as a whole [9-11].

\section{Conclusion}

The proposed recommendations justified the need for a marketing analysis in the real estate market not only in terms of supply, but also in terms of demand. The authors presented tools that allow carrying out these processes, relying not only on intuition analytics, but also on facts that can be measured and controlled.

The presented example of the analysis of demand in the housing market in Voronezh can be used as methodological recommendations that provide a comprehensive account of the quantitative approach to the assessment of demand from buyers in conjunction with the current supply.

The aim of ensuring a sufficient level of development of the construction industry, real estate market and regions acquires major importance under the crisis conditions of the economy and construction in general, when major companies are bankrupt and the rest of the market participants are fighting for higher profitability. Successful construction companies and developed real estate market are the driver of the entire national economy.

\section{References}

1. I.M. Kublin, V.I. Tinyakova, L.A. Shishkina, V.A. Polkanova, Ehkonomika, nauka, tekhnologii 1-1(26) (2017)

2. Y.B. Lavrinenko, V.I. Tinyakova, Vestnik Saratovskogo gosudarstvennogo social'noehkonomicheskogo universiteta 2(46) (2013)

3. Y. Lavrinenko, V. Pac, Nauchnyj vestnik voronezhskogo gosudarstvennogo arhitekturno-stroitel'nogo universiteta. Seriya: ehkonomika i predprinimatel'stvo 1(14) (2017) 
4. I. Provotorov, V. Gasilov, N. Anisimova, Problems of increased transport load as a result of implementation of projects of high-rise constructions 33 (2018)

5. Y. Panibratov, A. Larionov, Applied Mechanics and Materials 8, 725-726 (2015)

6. I.V. Ilin, A.I. Levina, O.Yu. Iliashenko, MATEC Web of Conf. 86, 05028 (2016) doi: $10.1051 /$ matecconf/20168605028

7. O. Kalinina, O. Valebnikova, Advances in Intelligent Systems and Computing 692, 1315-1322 (2018) doi: 10.1007/978-3-319-70987-1_139

8. R.S. Golov, V.V. Shilov, S.A. Silantiev, ASEE International Forum, Columbus 20766 (2017)

9. A. Jones, G. Fallon, R. Golov, European Business Review 12(4), 187-197, doi. 10.1108/09555340010336871

10. A. Seleznev, A. Mottaeva, L. Andreeva, S. Izmaylova, IOP Conf. Series: Earth and Environmental Science, 90, 012117 (2017), doi: 10.1088/1755-1315/90/1/012117

11. G. Dyakova, S. Izmaylova, A. Mottaeva, E. Karanina, IOP Conf. Series: Earth and Environmental Science, 90, 012218 (2017) doi :10.1088/1755-1315/90/1/012218 